International Journal of Social Sciences and Humanities
Available online at http://sciencescholar.us/journal/index.php/ijssh
Vol. 2 No. 3, December 2018, pages: 136 148
e-ISSN: 2550-7001, p-ISSN: 2550-701X
https://doi.org/10.29332/ijssh.v2n3.223

\title{
Pitra Yadnya Implementation for Hindu Heroes
}

CrossMark

I Dewa Made Suara a , I Putu Gelgel b, I Wayan Suka Yasa c

Article history: Received 8 April 2018, Accepted: 30 August 2018, Published: 21 November 2018

\section{Correspondence Author}

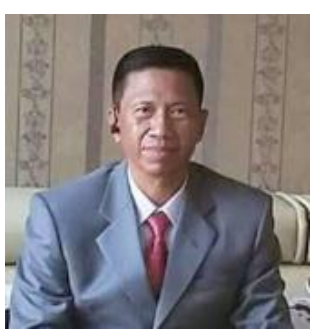

Keywords

Ceremony;

Community;

Hindu heroes;

Pitra yadnya;

Social interaction;

\begin{abstract}
In carrying out the obligations of the state (dharma negara) the Hindus who are designated as heroes to get the rights to the hero's cemetery are permanent. It means that they have a strong legal basis and their bodies are handed over to the state to be buried there. According to the concept of the death ceremony (pitra yadnya), the body must be immediately cremated (aben) to return the five basic elements (panca maha bhuta) to God. The study was intended to find why the pitra yadnya is importantly implemented for Hindu heroes in hero's cemetery Kalibata. A qualitative method was applied in the present study, structural functionalism theory, religious theory, symbol theory, and legal system theory. Pitra yadnya ceremony was important to be carried out for Hindu heroes in the hero's cemetery Kalibata, namely theologically accelerating the return of the panca maha bhuta to the Creator, sociologically involving the family, the community so that social interaction occurred, and family psychology was happy due to it can carry out pitra yadnya for the deceased. In this case, it was carried out in two stages, namely military ceremonies, and pitra yadnya. Sociologically, it was always involved family and society, therefore, social interactions occurred. The family psychology was happy to be able to carry out pitra yadnya ceremony hoping that the late was happy in the heaven (amor ring acintya). Juridically, the government accommodated in its implementation, while economically there was an economic turnaround, thus, the welfare of the community increased.
\end{abstract}

e-ISSN: 2550-7001, p-ISSN: 2550-701X ๑ Copyright 2018. The Author. SS Journals Published by Universidad Técnica de Manabí. This is an open-access article under the CC BY-SA 4.0 license (https://creativecommons.org/licenses/by-sa/4.0/) All rights reserved.

\section{Contents}

Abstract

1. Introduction .

2. Materials and Methods. 138

a Universitas Hindu Indonesia, Denpasar, Indonesia

b Universitas Hindu Indonesia, Denpasar, Indonesia

c Universitas Hindu Indonesia, Denpasar, Indonesia 


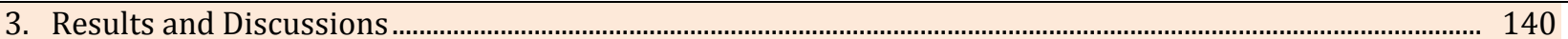

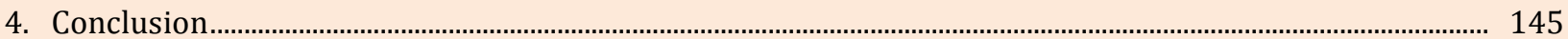

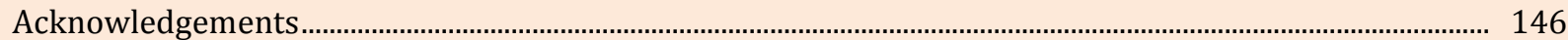

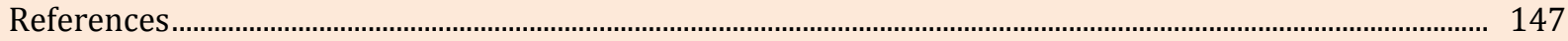

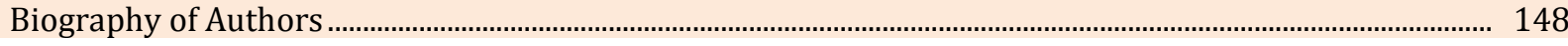

\section{Introduction}

Based on the effort to realize its social nature as an adhesive for various components to achieve its goals, humans form socioeconomic relations among themselves, namely the relationship between humans on the basis of existential motives. It means that the effort to fulfill the needs of life (both physical and psychological) in existential terms in the dharma of religion, namely carrying out the order based on the teachings of Hinduism. In addition, it is also existential in dharma agama, i.e., the fulfillment of order in accordance with the obligations and rights of the state rules as servants of the state.

Fulfillment of obligations and rights as servants of the state in this case the citizens, namely the Indonesian National Army/Tentara Nasional Indonesia (TNI) which is Hindu within the framework of the above human interrelationship, an existential motive that the social relations system is formed, especially within TNI. The effort to realize existential motives in a system of social relations is very complex due to the number of needs in human plurality with a plurality of differences. Therefore, the efforts made in this complex of interrelations require the need for one thing, namely an obligation and order about funerals for Hindu heroes at hero's cemetery/Makam Pahlawan Nasional Utama (MPNU) Kalibata.

The human existence previously started from the collectivity thinking pattern and in recent years all have been eroded by a change towards certain individualism and interests. Finally, unwittingly this leads to values about human rights which are often ignored and become debates of society currently. In fact, often individual freedoms ignore obligation and in society. Thus, citizens/TNI who are Hindus is always obedient and obedient to the legal system that applies to their unit including the Unitary State of the Republic of Indonesia/Negara Kesatuan Republik Indonesia $(N K R I)$. In managing their lives to reach Hindus in the Ministry of Defense but not only faced with the issue of diversity in the Hindu community, but also faced with a very complex issue of life and customary law that is different. Hindus also not only have to wrestle in religious life in the internal, but also externally faced with multiethnic environmental conditions, race, ethnicity, beliefs, religion, and others. By positioning themselves as citizens of the community, nation, and state, Hindus must also obey the rules that are applicable and regulated by the state (dharma negara) in this case at TNI unit.

The reality of the problems faced by Hindu societies, such as religious and social conflicts requires the commitment of all parties and the Hindu community. In this case, the effort to improve śraddhā and bhakti, knowledge, understanding, and meaning of the rules of faith (tattva), rules of virtue (susila), and rules of ceremony application (upacara) religious processes are expressed and implied in the sources of Hindu law (dharmaśāstra). The communal religious system that is always related to the situation and conditions of the community wherein social interactions will be able to foster religious or socioreligious social life based on virtue, honesty, truth (satyam), purity, purification (sivam), and harmony, beauty (sundaram). Thus, order, rule, togetherness, unity, harmony can be created, both individually and socially in community life as a knight. The use of rights at the Heroes Cemetery/Taman Makam Pahlawan (TMP) must be permanent (has a legal basis), meaning that the body must be buried in TMP. On the contrary, the public's understanding generally is that the corpse's spirit in question immediately gets a decent place. In fact, their family hopes that the spirit (atman) in the corpse can merge with Brahman. In this case, pitra yadnya is the best solution. The concept is the body must be immediately cremated (aben) to return panca maha butha to God.

Regarding the results of observations in the field, there are five Hindu religious people who have the right to be buried in TMPNU. However, they did not exploit this right, even though to get a place in TMPNU Kalibata through service to the country that exceeded the call of duty. This happens due to the family does not understand the kinds of pitra yadnya. In addition, there was also no socialization from facilitators and local leaders regarding pitra yadnya implementation for Hindu heroes. This means that the family has an understanding that if pitra yadnya does not have a corpse, it is considered that the deceased will not reach moksa or amor ring acintya. In addition, if buried in TMP it will be difficult in the pilgrimage process. Previously, it was stated that five Hindu religious people had the right to

Suara, I. D. M., Gelgel, I. P., \& Yasa, I. W. S. (2018). Pitra yadnya implementation for Hindu heroes. International Journal of Social Sciences and Humanities, 2(3), 136-148. https://doi.org/10.29332/ijssh.v2n3.223 
be buried in the TMP but were not buried in TMPNU Kalibata at the family request. The present study explains the reason why pitra yadnya is importantly implemented for Hindu heroes in TMPNU Kalibata?

\section{Literature Review}

Puspa (2009), stated that according to yama purwana tattwa, the funeral or corpse buried is to be avoided. That is, the ceremony is a means of liberating itself from the debt to the ancestors who have had a lot of merit in life. In addition, it purifies ancestral spirits not to be cursed into bhuta cuil that can pollute the universe so that, it can be united with the Creator. Suriyawan (2001), emphasized that the full death cremation implementation (ngaben ngelanus) in a matter not too long so it does not need to store and treat the body for a long time. This is in accordance with the rules of the DKI Jakarta Regional Government so that the costs required in ngaben ngelanus are not high. Patera (2008), confirmed ngaben implementation conducted in DKI Jakarta is certainly different from the Hindus who are in Bali. It was viewed from several aspects, for example, if there are Hindus who live in Jakarta, their bodies are not permitted to be lodged at home for more than 24 hours. So, it must be done immediately burial or burning.

Sumner (2014), mentioned included the form, function, and meaning of pitra yadnya, the implementation/procession of pitra yadnya ritual for Hindu heroes in TMPNU, and pitra yadnya implications associated with the rights to TMPNU for Hindu heroes. The form referred to in the discussion of the study was to discuss the procession of caring for the corpse, the treatment of the corpse when it had just died, the procession of bathing the corpse, the procession of confusion (ngeringkes), the cremation ceremony (pengabenan) with offerings (upakara), the delivery procession, nyekah and its ceremony. The functions discussed are religious, social, and aesthetic. The religious function explains that ngaben ceremony generally is to speed up the return of panca maha bhuta elements which are in the form of a rough human body (sawa) to be returned to their origin. The social function of ngaben ceremony is a vehicle for character building based on a culture of mutual cooperation, mutual respect, mutual care, and mutual care. The aesthetic function of ngaben ceremony is used as a vehicle for expressing the art is in every Hindu person, especially when decorating the corpse whose spirit is ready to face the Creator so that all are happy, both the deceased and the abandoned.

The purification meaning from the process of ngaben ceremony is karma that is performed during his/her life can be purified by the process of purification because Brahman is sacred. It means that before going to Brahman it should be sacred. Respect for ancestors is obliged to be executed (Kumbara et al., 2018). Pitra yadnya fact is sincere devotion to lift and perfect the position of ancestral spirits in order to merge with Paramatman (Brahman). Thus, all these ceremonies (yajna) become a major duty to their offspring.

\section{Materials and Methods}

\section{Theoretical Framework}

The structural-functional theory stated that everything that exists has a function towards others. Everything that exists will disappear by itself when it is no longer functional. Functional figures other than Durkheim (2008), like Malinowski (2013), called it functionalism, while Graib (1992) and Parsons (1964), called it structural functionalism. Malinowski (2013), stated that various elements of culture that exist in society function to satisfy a series of instinctive desires for human life needs (human basic needs) (Koentjaraningrat, 1980). The religious element has a function to satisfy a series of instinctual desires for the needs of human life for peace of life.

Spencer (1895), emphasized structural-functional theory, which was developed by Cieszkowski (1838), that society has certain structures and functions. The above opinion is further strengthened by Durkheim (2008), stated that as a whole, society is an organism that has its own reality with a set of needs and certain functions that must be fulfilled by the parts that are members to remain lasting and vice versa will be pathological. This theory was used to dissect the first issue about the importance of carrying out pitra yadnya for Hindu heroes.

Koentjaraningrat (1982), explained that religious ceremonies are an element in the lives of human tribes in the world. Thus, an analysis of religious ceremonies in such a society and culture is considered an attempt to find the principles of ancient religion and attempts to solve the problem of the origin of religion. Hertz (1976), considered that the death ceremony is always carried out by humans in the context of customs and social structures of the 
society that manifest as collective ideas. Thus, the ceremonies analysis of the deceased must be viewed from the point of view of the community's ideas.

Hertz (1976), viewed that the collective idea of the symptoms of death found in many tribes in the world means a process of transition from a certain social position to another social position, namely the social position to a social position of the world of spirits. The death ceremony is an initiation ceremony. Smith (1927), explained the offering ceremony. In this case, the offering ceremony does not originate from the analysis of the belief system or the doctrinal study of religion but based on the ceremony. The first idea about the problem is that besides the system of belief and doctrine, the system of ceremonies is also a manifestation of religion or religion that requires special study and analysis. The second idea is that religious or religious ceremonies which are usually carried out by many religious or religious community members concerned together have a social function to intensify community solidarity.

Koentjaraningrat (1997), explained that religion is a belief system adopted by traditional societies. Religion is all systems of human behavior to achieve a purpose by relying on the will and power of spirits, such as spirits, gods, and so on that occupy nature. According to Durkheim (2005), the basics of religion are divided into five religious components, namely (1) religious emotions that cause humans to be encouraged to behave religiously, (2) a belief system or human images of the world shape, the occult world, and so on, (3) religious rites and ceremonies that aim to find relationships with the occult world based on the belief system, (4) religious groups or social units that conceptualize and activate the following religions with a system of religious ceremonies, and (5) physical instruments used in religious rites and ceremonies. In addition, Taylor (1994), suggested the origin and essence of a universal element such as religion or religion. Furthermore, it is stated that religious human behavior occurs because (1) humans begin to realize the existence of the concept of spirit, (2) humans recognize the existence of various symptoms that cannot be explained by reason, (3) human desire to face various crises that are always experienced by humans in their life, and (4) extraordinary events experienced by humans in the natural surroundings.

The origin of religion is human consciousness of the spiritual concept. This is caused by two things. First, the appearance is the difference between living things and dead objects. Thus, motion in nature (i.e. life) is caused by a force that is beside the physical body, namely the soul (spirit). Second, dream experience, in a human dream she/he sees himself in places other than where she/he sleeps. Humans begin to distinguish between physical bodies that are in bed and other parts of themselves, namely the soul (spirit) who goes to another place. Relating to this research religious theory is used to study more about the pitra yadnya ritual for Hindu heroes.

\section{Research design}

Based on the above problems in this study, qualitative methods were used with the nature of analytical descriptive research. Descriptive means to describe or examine the problems of the legal system, especially regarding the perspective of legal structure, a legal substance, and legal culture in the paradigm of Hinduism and its existence as the substance of Hindu law. The methods used are a literature review, interviews, and history. The historical method referred to is the literary approach, which refers to biographies and bibliographies. Qualitative research is a generic term, which includes investigative methodologies such as historical, descriptive, development, case studies, correlational studies, comparisons and causes, experimental quasi or no quasi (Isaac, 1971). The characteristics of qualitative research do not emphasize quantum or number, but rather emphasize in terms of quality naturally because it involves understanding, concepts, values, and characteristics inherent in the object of research found in the field relating to the implementation of pitra yadnya for religious heroes Hindus at TMPNU Kalibata.

\section{Data collection technique}

Research is an activity (scientific) taken through a series of long processes (Bungin, 2003). The scientific term contains an understanding based on empirical facts (not personal ideas) obtained from the careful and objective investigation. This research refers to the existence of dharma siddhyartha teachings as a legal substance. Thus, the meaning of more research is translated into the perspective of the existence of a teaching. The meaning of research in this review is a process in the form of a series of steps carried out in a planned and systematic way to obtain solutions to problems that have to do with the existence of teachings in dharma siddhyartha texts as legal substances in the Hindu legal system. This research is more directed at the type of analysis of the legal system implementation for the rights of heroes who are Hindu. Therefore, a number of methods that support and give priority are used specifically to the teachings in the dharma siddhyartha texts relating to their existence in the DKI Jakarta and surrounding areas.

Suara, I. D. M., Gelgel, I. P., \& Yasa, I. W. S. (2018). Pitra yadnya implementation for Hindu heroes. International Journal of Social Sciences and Humanities, 2(3), 136-148. https://doi.org/10.29332/ijssh.v2n3.223 
Data collection technique is one of the important stages in research, namely the way that researchers take to get the data needed in accordance with the problems studied. Data collection in this study included observation techniques, interviews, and document studies.

\section{Data analysis technique}

According to Sugiyono (2012), data analysis is the process of searching for and systematically compiling data obtained from interviews, field notes, and documentation. Data analysis is conducted by organizing data into categories, describing into units, synthesizing, arranging into patterns, choosing which ones are important and which will be learned, and making conclusions so that they are easily understood by themselves and others. The technique of analyzing qualitative research data was analyzed in the field. According to Miles \& Hubermen (1984), the activity of data in qualitative analysis is carried out interactively and continues continuously to completion. Data analysis relates to the implementation of a legal system for the rights of heroes who are Hindu. The steps that must be conducted i.e., data reduction, data display, and conclusion or verification.

\section{Results and Discussions}

\section{Theological Reason}

A pitra yadnya ceremony is a form of relative's worship for Hindus to their families who have died, by treating the dead bodies and spirits in a respectful manner according to Hindu teachings. The respectful treatment is determined based on the sacred text written in lontar or scripture. Lontar or religious books that were used as guidelines by priests (sulinggih) in Indonesia, especially in Bali, there are three main, namely yama purwa tattwa, yama purwana tattwa, and yama purana tattwa. The contents of the three holy books are more technical in nature, meaning that they explain more about the means and process of pitra yadnya ceremony. In the introduction to the book over the third translation of the lontar, it is explained that (1) yama purwa tattwa places more emphasis on the description of the offerings of pitra yadnya; (2) yama purwana tattwa describe the procedures for giving services to deceased people; and (3) yama purana tattwa describes the form and use of tattoo for deceased people (Tim, 1997). The theological reason is related to the pitra yadnya ceremony was carried out as a form of devotion to the deceased. This is in accordance with what was conveyed by informant I Nengah Dana interviewed on August 14, 2018. He stated as follows.

\footnotetext{
"The reason of Hindus executed the pitra yadnya was as a form of kindness to relatives of the Hindu people to his/her deceased family, by treating the dead bodies and spirits in a manner respected by Hindu teachings. The courtesy is based on the sacred texts written in the lontar or holy book."
}

Other informants Ketut Sudarsana (interviewed, August $18^{\text {th }}, 2018$ ) stated that:

"Pitra yadnya was carried out as a form of devotion to the relatives of the Hindus to his/her deceased family, by treating the dead bodies and spirits in a manner respected by Hindu teachings. The respectful treatment is based on the sacred texts written in the lontar or scripture."

The above interview it is clear that the theological reason for pitra yadnya implementation is as a form of relative's charity of Hindu to his/her family who died. In this case, the bodies and spirits of the deceased were treated in a manner respected by Hindu teachings.

In yama purwa tattwa, yama purwana tattwa, and yama purana tattwa briefly stated theological reasons for the need to guide people to die by ngaben. Yama purwana tattwa book (Tim, 1997), explained it from the aspect of mythical myths. Unlike the saint, namely padanda atap ender. She/he performed samadhi (tapa) with the aim is to complicate the spirit sins of the deceased, so that the spirit becomes holy and can be led to reach heaven (swarga bhuwana), namely the heavenly realm. This means that the spiritual journey to the underworld does not get a hitch. Their samadhi received the blessing of Bhatari Durga in the form of Bharata Yama.

"Tingkah angupakara sawa sang mati, agung alit, nista madya utama, maka patuting wulah sang magama Tirtha ri balirajya, kewala wwang mati bener tan wenang mapendem, mande mageseng juga, saika upacaranya, prasidha sang atma molih ring Bhatara Brahma, apitwi tan pabeya, swasta ring Sang Hyang Agni sida manggih rahayu sang hyang atma". 


\begin{abstract}
Translation:
The ceremony behavior for the body of a deceased person, both with large and small ceremonies, or with simple, medium, or large ceremonies, should be in accordance with what is held by the Hindu community in the kingdom of Bali. As long as the person dies properly, it should not be buried, but burned in accordance with the religious ceremonies. Thus, the spirit of the deceased person can reach the realm of Bhatara Brahma. Even though ngaben is without a large fee, the spirit will be holy by Sang Hyang Agni (holy fire of ngaben). That is how the spirit of the deceased gets good."
\end{abstract}

From this quote, it can be understood that the purpose of ngaben is to return the body to its origin and purify its spirit. This can be done by burning it with the holy fire of ngaben.

Holy fire is a sacred means that is believed to be effective in returning the body and purification of the spirit from its attachment to the body. It is a manifestation of tapa, which is a spiritual effort to purify oneself. Tapa in the theological aspect is the manifestation of the activity of Bhatara Brahma or Dewa Agni, namely to deconstruct quickly and effectively the corpse in order to immediately return to bhuwana agung, namely the universe. Solid element returns to prethiwi (solid or earth element); liquid element returns to apah (liquid or water element); heat element returns to agni (element of fire or heat); the air element returns to wind (air element); and the element of space returns to akasa (element of rung or ether). The five elements in question are bhuwana alit become bhuwana (universe). In other words, the five elements of the body called bhuwana alit can immediately return to bhuwana agung through ngaben ceremony. This is analogous to purifying gold. To find pure gold, the goldsmith burned it with fire in such a way that it was time to get pure gold. Similarly, the spirit of the person who died before ngaben ceremony is performed, the spirit is believed to be in a dirty state, which is littered with attachment to its body.

The use of holy fire in Hindu ceremonies is an ancient tradition that continues to this day. The glory of fire, both its function and meaning, has been stated in $R g$ Weda book. The fire spirit is Lord Agni who in Bali is better known as Lord Brahma. He is an aspect of God in his function as (1) purohita, namely the god of the yad leader who ushered in the offerings of Hindus immediately to his destination. In its development it was replaced by priest (sulinggih), (2) protector of worshipers, (3) giver of blessings of light, (4) source of energy or life, (5) source of knowledge, (6) pitamaha, i.e., the earliest ancestor of all beings, and (7) universal witnesses in thirteen manifestations called Sang Hyang Tryodasa Saksi. Therefore, in Catur Weda, Agni is the most popular deity, even referred to as the god of the gods. In $\mathrm{Rg} W e d a, A g n i$ was a god who was first worshiped before worshiping another god. This can be known through the initial mantra of $R g$ Weda (I.1.1-5) as follows.

\author{
Agnim ile purohitam \\ yajnyasyam dewam ritdwijam \\ hotaram ratna datanam. \\ Agniih purwebhir rsirbhir \\ idyo nutanair uta \\ sa dewameha waksati. \\ Agnena rayim asnawat \\ posam ewa diwe-diwe \\ yasasam wirawattamam \\ Agne yam yajnam adhwaram \\ wiswatah paribhur asi \\ sa id dewesu gacchati. \\ Agnir hota kawikratuh \\ satyas citra srawatastamah \\ dewo dewibhir agamat. \\ Translation: \\ We adore Agni, the manifestation of God in Your aspect as the principal priest of the universe, who performs activities based on \\ the eternal law, which nurtures and nurtures it with excellence. Yes, Agni is a source of inspiration, wealth, strength, and \\ prosperity that grows. Yes, Agni, You are the protector of sacred sacrifice, creator of the universe that is not obstructed. May \\ your blessings come from all directions for truth seekers? Yes, Agni as a source of energy and knowledge, givers and \\ performers. You are the unparalleled divine authority of truth. May You be the source of inspiration for truth seekers.
}

Fire certainly will not be able to ignite without fuel. The main fuel is oil, which is the element that represents apah (water and/or oil that comes out from selected firewood). Theologically, spirit apah is Lord Vishnu. In ngaben ceremony, apah element is manifested in the form of various types of tirtha (holy water), namely the holy water of pangabenan in the form of tirtha panembak, tirtha pabresihan, tirtha panglukatan, tirtha pangentas, and tirtha kahyangan. Each tirtha is believed to have a function (1) opening shackles, (2) cleaning dirt, (3) complicating sin, (4) giving way to the spirit in order to be free of worldly bonds, and (5) give blessing and put the spirit as dewa

Suara, I. D. M., Gelgel, I. P., \& Yasa, I. W. S. (2018). Pitra yadnya implementation for Hindu heroes. International Journal of Social Sciences and Humanities, 2(3), 136-148. https://doi.org/10.29332/ijssh.v2n3.223 
hyang or dewa pitara (our parents that has been gods). Therefore, before being burned, the body was treated with the intended tirtha. However, water and holy fire will not be able to carry out their functions without being helped by bayu (holy air) which is manifested in special mantra in ngaben called mantra pamralina. Spirit bayu (wind) is Dewa Iswara or Rudra. So, in ngaben ceremony, the three main gods called Sang Hyang Trimurti were asked for their presence and blessing to perform their spiritual functions in a synergistic manner so that ngaben ceremony could run well.

In the context of the use and control, the real functions of agni, tirtha, and bayu, sulinggih (priest) were invited and crowned with a sacred position, namely as Shiva Sakala (representative of Lord Shiva in the world). Shiva is the god of worship who is the One. It is believed that from Lord Siwa, the God Trimurti was created and only Lord Siwa could rule Lord Trimurti to carry out their duties in ngaben ceremony. Therefore, the priest in his position as Shiva Sakala has the authority to carry out his function for mapuja (leading the ngaben ceremony). The purpose of worship is to (1) obscure the corpse, (2) merge all leteh (bad luck and sin) so that the spirit becomes pure and purity, (3) the pure spirit is then led to heaven, and (4) then seizes the spirit as a devotee (holy servant) Bhatara Guru (Siwa) who is married and worshiped by the family in Palinggih kemulan (temple in family house).

\title{
Sociological reason
}

Hindu literature explained that humans were the most perfect creatures on this earth. It is stated that because only humans are destined to have bayu (power of motion), sabda (speech), namely the ability to process words or speech, and idep (thoughts), namely the ability to analyze something that is on its side. Another creation, namely plants are destined to only have bayu. Animals are doomed to only have bayu and sabda. These advantages should only be used to study/sort so that something or problem around it can be understood which is good, which is bad. Related to that, Maha Rsi Wararuci explained as follows.

\author{
Manusah sarvabhutesu, \\ vartate vai subhasubhe, \\ asubhesu samavistam, \\ subhesvevakarayet; \\ Translation: \\ Among all living creatures that are born as human beings only can distinguish good or bad things. Melt into the good deeds of \\ all these deeds. That's point of being human (Kajeng et al., 2003).
}

The ability to think that leads human to understand that they cannot live alone. In order to live a decent life, humans need help each other and vice versa. Humans need help besides being able to provide help to their fellow beings. Humans have the instinct to connect with other people. Living with humans can fulfill other life needs, both physical and spiritual needs. Only by living with humans can develop as normal humans. According to Bouman (2005), humans can be called humans when together with other humans.

As social beings, humans cannot live alone. In this case, all the processions were carried out by the society, tempek (smallest group under banjar), banjar (small than a village). That is what motivates to strengthen family relationships. This means that this religious social function can strengthen human relations in this life (interviewed, Anak Agung Oka Puspa, July 15 ${ }^{\text {th }}$, 2018). As it is known pitra yadnya has been carried out in Bali since ancient times. In the implementation certainly involve the wider community, especially the Hindu community in Bali, even non-Hindu communities.

The involvement of the community in the implementation of pitra has led to social relations among community members, both individually and in groups. The existence of these relationships raises interactions between them when carrying out all activities or activities related to the yadnya pitra ceremony while creating social actions. In pitra yadnya implementation as described above, there is social interaction, both in the family and in the community. As a result of their interaction, they receive influence, both directly and indirectly, in social relations between them. The interactions made their relationship will become closer, better, more harmonious, due to them mingled and were involved in the series of pitra yadnya ritual activities. The social interaction is a relationship between individuals two or more that influence, change, or improve another individual, or vice versa.

The sociological reasons above were also conveyed by Wisnu Bawa Tenaya (interviewed, January $11^{\text {th }}, 2018$ ), namely pitra yadnya implementation can certainly involve the wider community, especially the Hindu community in Bali, even non-Hindu communities. The community involvement the implementation has led to social relations among community members, both individually and in groups. This relationship creates interaction between them 
when carrying out all activities or activities related to pitra yadnya ceremony. That is, social interactions occur, both among families and communities.

Furthermore, informant Nengan Dana (interviewed, February $24^{\text {th }}, 2018$ ) stated that pitra yadnya implementation could certainly involve the wider community, especially the Hindu community in Bali, even non-Hindu communities. The involvement of the community in the implementation of pitra yadnya has led to social relations among community members, both individually and in groups. These relationships lead to social interaction, both within the family and among the community they carry out all activities or activities related to pitra yadnya ceremony. Other sociological reasons related to pitra yadnya implementation for the heroes who were buried in Kalibata were because they followed the conditions set by their Desa Pakraman (group of banjar). That is, in the implementation of the decree that has been determined the way, which is adapted to the social situation and the situation included "desa, kala, patra" (place, time, state) the method carried out has been determined in tattwa, etika, susila (thatness, ethics, and morality) as follows.

\begin{abstract}
Iti Yama Purwwana -Tattwa sahindikan karma wang mati mapendhem, yan satahun, dwang tahun tigang tahun, mwah salawasnya tan maprateka tawulan wangke ika. Hana pawarah Bhatara Yama Munggwing sastra, leng nira: Uduh Sang Pandita ring janaloka, yan ana wang mati, sumuruping Ksiti dharani, haywa sira mreteka ngarepang tahulan wangke ika, phalanya tan prasiddha hilang letuhing Sang Atma, tan prasiddha kaprateka, apan wangke ika mulih ring jroning garbha Sang Hyang IbubPrethiwi, waluya sampun mageseng, mawak tanah, saletuhing prethiwi rumaket ring wangkeika. Teka wenang sang Pandita ngarcana hayu sang Atma kaprateka.
\end{abstract}

Mangke wenang sang Pandita hanugraha ring manusa loka ngangge awak-awaka sang mati, siddha mulih Atmanya ring Bhyomantra, hamanggih hayu, siddha Nirmala hilang letuhing Atma katekaning twannya. Wangkenya wang mati gawenang awak-awakan antuk cendana, panjangnya selengkat ring amusthi, melarnya (lebarnya) petang jari, masurat pancakshara, Dasaksara, Tri-akshara, Rwa bhineda, ongkara mule, mwah wong-wongan, idep wangke wang mati ika. Dulurin upakara atiwa-tiwa, ring desa wenang inupakara, tan ana salahnya, mwah wangke ne mapendhem, wenang gagah ring pabresihan ika ring esuk. Tulangnya wasuh ring toya kumkuman, toya bungkak nyuh bulan, genahang ring setra gawenan kuwu. Sedurunge dina pebresihan ulapin atma sang mati, tebusana ring Prajapati, kinon mulih ring dunungannya, tirta Prajapati wenang sinirat ring ksiti darana wwang pinendem, pring sunuk wenang lina, tenah kelebur awu, kinon mulih ring dunungannya sedhahan kawah.

\title{
Translation:
}

This is the sacred book of Purana Tattwa, regarding the procedure of the dead man who is buried. Whenever the length of a year, two years, three years, and forever is not believed to be the bones of the corpse, this is an indication of God Yama has been set in religious literature, this is the clue. Oh... priests (pandita) of this world, if any man die, if he is buried, do not have to talk with the corpse at home, his/her reward can not get rid of the impurities of the atma (spirit), can not be recited as the corpse returns to under Sanghyang Ibu Pertiwi, as has been, already in the ground, the dirt of Pertiwi is attached to the body.

In the life of traditional village community in Bali, there is a belief, namely that the body is buried for more than three years to eight years, sekama-kama (as desired) can be administered (ngaben) no later than three years. If the burial was not accompanied ngentas kasen "tirtha pengentas" and without mapajati, in a year must be arranged for ngaben. If it passes the specified time limit, it will be difficult to read it because the pitra (the dead people) has changed to become sang bhuta cuwil, and numandang for not getting a place in Pitra Loka (heaven). Nagaben is intended to increase pitra into pitara, cannot be realized. The atma who is very proud is suffering due to they have not got a place. They appear everywhere like their original form before they die. Sometimes, in families and sometimes waiting for their grave, their movements are fast but full of feelings of helplessness. This has a bad effect, bringing chaos to the family and Desa Pekraman. Over time, the atman who appears can become a ghost, as mentioned in the Garuda Purana, i.e., sometimes people who have died come and haunt people. An improper ngaben ceremony brings atma numandang who is countless ghosts and bhuta cuwil. This can bring disruption to the family with the following characteristics.

The community never gets happiness, looking for clothing and food is very difficult because it rarely rains and the season is not right, a lot is done, but the results are not visible. In addition, various kinds of community diseases cannot be cured, human life is getting shorter, behavioral and moral diseases are declining, evenings are like daytime, daytime like nighttime. The other thing is people really appreciate the rich, the leaders ask for mercy from the people, all people fight for power, scholars and brahmins devote themselves to the rich, often have fights and killings, many animals die suddenly, among friends and family hostility occurs, there are unexpected disasters, children oppose and deceive their parents. Another disaster, namely the Brahmana Purohito were insulted, the harvest began not to work as it should, there was a fire from unclear causes, husbands and wives always quarreled, the mountains often erupted, the dry season was hard to get water and in the rainy season, there were floods where.

Suara, I. D. M., Gelgel, I. P., \& Yasa, I. W. S. (2018). Pitra yadnya implementation for Hindu heroes. International Journal of Social Sciences and Humanities, 2(3), 136-148. https://doi.org/10.29332/ijssh.v2n3.223 
In addition, there is also no rain, but there are flash floods, religious literature is often disputed, most people like to denounce tradition and religion, one religion and the other insult each other, humans often have chaos and equality, hatred happens everywhere. Another problem is that there is a war between countries, religion is a place of business and fraud, the robbery takes place during the day, and humans increasingly like their kind. Therefore, the family feels bad, if they do not carry out pitra yadnya ceremony for their families that have not been attended to. He/she felt embarrassed and felt bad for the people. That is, they are afraid of the social sanctions that will be given by their traditional manners.

As stated by informant Jero Mangku Danu (interviewed, February $8^{\text {th }}$, 2018) that the consensus is anyone who does not carry out the obligation to serve his/her late family according to tradition is seen as a member of a sinful society. Based on the villager's agreement, the person deserves social sanctions. To avoid social sanctions, residents of the deceased are obliged to carry out ngaben ceremony for their deceased families.

In addition to the two sociological reasons above, another reason is pitra yadnya ceremony is carried out because the ceremony can foster a sense of mutual cooperation in the family and society. This is in accordance with the traditional philosophical foundation of the village, namely tri hita karana sukerta tata pawongan which teaches that life in society should be carried out with a relationship of harmony between fellow human beings ...... This motto reflects the ideals and desire to always live in togetherness in a state of joy and sorrow, facing all life challenges. The real manifestation in the application of the concept in everyday life raises several operational concepts in Balinese society, such as ngoopin, mapitulung (mutual cooperation to help the work of others voluntarily without pay).

Unlike conveyed by informant Ketut Sudarsana (interviewed in July $10^{\text {th }}, 2018$ ), that sukerta tata pawongan teach a life relationship between the harmony of fellow human beings ...... sagalak saguluk salunglung sabhayantaka (togetherness and helping each other fellow citizens), this motto reflects the ideals and desire to always live in togetherness in a state of joy and sorrow, facing all the challenges of life. The real manifestation in the application of the concept in everyday life raises several operational concepts in Balinese society, such as ngoopin, mapitulung (mutual cooperation to help the work of others voluntarily without pay). In addition, ngaben ceremony also has the function of strengthening the sense of kinship, mutual cooperation media, and desa pakraman meeting.

It can be seen from the information from the informant above that pitra yadnya was carried out because the community followed the tradition in desa pakraman. The community is still submissive and obedient to habits and or rules that have been generally applied and used guidelines in community life in desa pakraman are still carried out (loka dresta). Dresta refers to rules understanding or rules sets that govern people lives in desa pakraman or banjar. Dresta was born from a feeling of justice and propriety sense society in order to create a harmonious relationship with God, fellow humans, and the natural environment. In Bali, there are four parties called catur dresta. Purwa dresta often called kuna dresta are habits and or rules that are used as guidelines in people's lives that have been inherited from generation to generation and have been valid since ancient times. It usually involves morality in community relations such as the procedure for dressing when going out and when going to a meeting (pesangkepan). Loka dresta is a habit and or rules that have been generally applied and used guidelines in people's lives in a particular place or location. For example, not to burn dead bodies in Trunyan area (Bali Aga). Desa dresta is not much different from the loka dresta, which is a view that has been tradition and only applies in a certain desa pakraman. For example, ngusaba is generally conducted in the villages of East Bali, while in West Bali it is not normal.

Sastra dresta is the basic or main rules derived from Hinduism teachings refer to the Vedic scriptures. The literature drafts are a set of written legal principles that concern the interests of the people and are deemed appropriate by the local community. For example Manawadharmasastra, Sarassamuscaya, Bhagawadgita, etc. In this case, there is lontar containing practical instructions for carrying out yadnya ceremony. Next to dresta, every desa pekraman has awig-awig. Awig-awig is one form of Balinese local wisdom that regulates what is appropriate and what is inappropriate, what is permissible and what should not be done in community life. Awig-awig grows out of a sense of justice and propriety in the local community even though sometimes the customary rules are not in line, even contrary to state law (Gelgel, 2007).

\section{Psychological reason}

In addition to the theological and sociological reasons as outlined above, the implementation of pitra yadnya for the hero who was buried in TMP Kalibata was also for psychological reasons. One of the psychological reasons for carrying out pitra yadnya ceremony was that the family felt free from guilt because they had carried out ceremony. In Hinduism teachings, the human body is returned to its origin. Humans consist of three elements included mayat 
(dead body), jiwa, and atman (corpse, soul, and spirit). Manu Smrti stated that humans consist of three layers, namely raga sarira, sukhma sarira, and antahkarana sarira. Humans who have died are manifested in their reka upakara and ceremonies, as follows.

1) Raga sarira or stula sarira is a rough body, that is, a body that is born because of lust between mother and father. If the ceremony is symbolized by pengadegan or pitra lingga.

2) Antahkarana sarira or sang hyang atma, which is what causes this body to come alive. In pitra yadnya ceremony is symbolized by Puspa Lingga, the binding of the three elements, symbolized in the form included pisang jati (banana), damar kurung and api angenan, which have the meaning as a ray of Sang Hyang Atma.

3) Sukhma sarira is a subtle body made of the universe of thoughts, feelings, desires, and passions (citta, budhi, and ahamkara or tri guna). In pitra yadnya ceremony is symbolized by suratan kajang (Sanskrit written mantra in the fabric when).

Ngaben ceremony aims to restore the corpse, soul, and atman elements to its origin, namely panca mahabhuta, panca tan matra, and panca kamendriya in bhuana agung. Besides that, it is also a sanctification ceremony for the deceased person to escape the bondage of papa klesa. The hope is that the atman can return to the source of life according to subha-asubha karma. All should be carried out with a very respectful and devotional feeling to the ancestors who are prescribed. From ngaben ceremony until atma wedana (memukur) occurs five times the process. After he/she died Sang Hyang Atma was called preta. After carrying out samskara (pangaskara/penyucian/purifying) and the ceremonial ceremony at the grave of Sang Hyang Atma called pitra. After ngerorasin or mamukur accompanied by mendak in the sea immediately and munggah don bingin of Sang Hyang Atma is called pitara. After maligya and ngeluwer accompanied mendak nuntun (pick up and put) and nyegara gunung (ceremony at traveling in the mountain) and put in the family temple of Sang Hyang Atma called dewatadewati (dewa hyang) (the holy of the dead person). In lontar of Dewa Tattwa is a rule about the ethics code that must be passed on when performing the ceremony is as follows:

\footnotetext{
Kramaniya sang kumingkin akarya hayu, sanistha madhyottama, manah lega dadi hayu, ayuwa ngalemdrewya mwang kamungutan kaliliraning wang atua, ayuwa angambek rodra mwang ujar gangsul, ujar menek juga kavedar denira, mangkana kramaning sang ngarepang karya hayu, ayuwa simpangin budhi mwang rodra.

Translation:

Procedures for those who are prepared to carry out their offerings (yadnya) in the form of nista (small), madya (middle), or uttama (big). It should be based on a pure and sincere mind, not to attach too much to the possessions. Take care of behavior, not to speak harshly or angry. Good, sweet, pleasant words should be said. So that, yadnya purity is astiti bhakti based on the purity of heart. That is what must be maintained to achieve a common goal.
}

Excerpts of lontar of Dewa Tattwa explained social ethics forms must be created, applied, and safeguarded by Hindus in making bebanten (offerings) and the means of completing them from the planning until the ceremony ends. Every citizen is obliged to foster an attitude of manners, sila karma, self-control (through thoughts, words, and deeds) starting from planning, implementation, to completion. A happy face will cause and awaken the image of maturity in everyone (suri sampat). If it is viewed from the togetherness, through the implementation of the yadnya ceremony Hindus are guided to always learn to sharpen the mutual compassion nature, sharpening and nurturing, salulung sabayantaka (harmonies at all things). In the activities of ngaben ceremony, there is a very important social interaction and gives a very big role in realizing wholeness in everyday life. All of these things happen because a social interaction that includes a sense included togetherness, unity, kinship, and responsibility, devotion, both to others and to Ida Sang Hyang Widhi Wasa (God).

\section{Conclusion}

The implementation of pitra yadnya in the form of ngaben ceremony for the worship of Hindus at TMPNU Kalibata is based on several reasons. First, the theological reason that eschatological texts and Hindu saints in Indonesia teach that the person corpse before cremated is seen as bad luck (ngaletehin) "pollutes the sanctity" of the village (desa pakraman). Second, the sociological reasoning that the belief system meant, in turn, became religious emotion (sradha) of the adherent community. This was then manifested in the form of ngaben ceremony.

Suara, I. D. M., Gelgel, I. P., \& Yasa, I. W. S. (2018). Pitra yadnya implementation for Hindu heroes. International Journal of Social Sciences and Humanities, 2(3), 136-148. https://doi.org/10.29332/ijssh.v2n3.223 
Consequently, anyone who does not carry out the obligation to service his/her late family in accordance with tradition is seen as a sinful member of the community and based on the agreement of the villagers deserves social sanctions. To avoid social sanctions, residents of the deceased carried out ngaben ceremony. In addition, ngaben ceremony also has the function of strengthening the kinship sense, mutual cooperation media, and desa pakraman. Third, psychological reasons carrying out ngaben ceremony, the family of the deceased felt free from guilty feelings and became happy. This happened because the debt of gratitude to the deceased (ancestor) called pitra rnam was successfully repaid. Through ngaben ceremony, the spirit is believed to have become a saint called dewa pitara or dewa hyang who is being held in a family sanctuary. With his/her position as the god of pitara, the deceased spirit can carry out his function to become a spiritual teacher, protector, and giver of family blessing.

\section{Acknowledgments}

We would like to thank the rector of Universitas Hindu Indonesia, co-promotor and director of the Postgraduate Program of Universitas Hindu Indonesia, for all their guidance. The head of the doctor of religion and culture study program, Universitas Hindu Indonesia postgraduate program. The secretary of Universitas Hindu Indonesia postgraduate for their direction and information, promotor for all the guidance and facilities provided during the lecture. The lecturers who cannot author mention one by one with full patience and perseverance to provide material in the lecture process. The informants/speakers were so patient and sincere to take the time to help the writer. Beloved wife and children, for all their support, motivation, and prayer, all parties for all assistance and good cooperation so that the present article can be completed on time. 


\section{References}

Bali, K. D. B. (1997). Teks, alih aksara dan alih bahasa lontar.

Bouman, A., Heineman, M. J., \& Faas, M. M. (2005). Sex hormones and the immune response in humans. Human reproduction update, 11(4), 411-423.

Bungin, B. (2003). Analisis data penelitian kualitatif: Pemahaman filosofis dan metodologis ke arah penguasaan model aplikasi. Jakarta: PT Raja Grafindo Persada.

comte Cieszkowski, A. (1838). Prolegomena zur historiosophie. Veith.

Durkheim, E. (1982). What is a social fact?. In The rules of sociological method (pp. 50-59). Palgrave, London.

Durkheim, E. (2005). Suicide: A study in sociology. Routledge.

Durkheim, E. (2018). The division of labor in society. In Inequality (pp. 55-64). Routledge.

Durkheim, E., \& Swain, J. W. (2008). The elementary forms of the religious life. Courier Corporation.

Gelgel, I. P. (2007). Kearifan lokal masyarakat bali dalam pembangunan hukum pariwisata di tengah arus globalisasi perdagangan jasa (Doctoral dissertation, Fakultas Hukum).

Graib, I. (1992). Teori-teori Sosial Modern; dari Parsons sampai Habermas, terj. Paul S. Baut, T. Effendi, cet. II. Jakarta: Rajawali Pers.

Hertz, J. A. (1976). Quantum critical phenomena. Physical Review B, 14(3), 1165.

Isaac, S. (1971). M ichael, W illiam B. Handbook in Research and E v alu atio n. San Diego, C a lifo rn ia: Kanpp.

Kajeng, I. Nyoman dkk.(2003). Sarasamuscaya. Jakarta: PT Pustaka Mitra Jaya.

Koentjaraningrat, F. (1982). Anthropology in developing countries. Indigenous Anthropology in Non-Western Countries.

Koentjaraningrat, K. P. H. (1997). Anthropological aspects of cultural tourism. Tourism and Heritage Management, 101.

Koentjaraningrat, R. M. (1980). The theory of Indonesia's tropico-colonial economy. Sociology of Southeast Asia: readings on social change and development (ed. by Hans-Dieter Evers), Oxford University Press, Kuala Lumpur.

Kumbara, A. N. A., Wiasti, M., \& Dewi, A. S. K. (2018). Transformation of siwa-sisya relationship within Hindu religiosity. International Journal of Linguistics, Literature and Culture, 4(5), 1-13.

Malinowski, B. (2013). Crime and Custom in Savage Society:[1926/1940]. Routledge.

Miles, M. B., \& Huberman, A. M. (1984). Qualitative data analysis. Beverly Hills.

Parsons, T. (1964). Levels of organization and the mediation of social interaction. Sociological Inquiry, 34(2), 207220.

Patera, I. W. (2008). Sanggah Dawa in the Life of Pacung Community. Burials, Texts and Rituals: Ethnoarchaeological Investigations in North Bali, Indonsia, 1, 119.

Puspa, J., \& Rahardja, C. T. (2009). Market Mavenism: Its Contribution in Building Consumer's Trust. Gadjah Mada International Journal of Business, 11(1), 21-35.

Smith, W. R. (1927). Lectures on the Religion of the Semites: the Fundamental Institutions. Ktav Publishing House.

Spencer, H. (1895). The principles of psychology (Vol. 1). Appleton.

Sugiyono. (2008). Metode penelitian pendidikan:(pendekatan kuantitatif, kualitatif dan R \& D). Alfabeta.

Sumner, A., Yusuf, A. A., \& Suara, Y. (2014). The Prospects of the Poor: A Set of Poverty Measures Based on the Probability of Remaining Poor (or Not) in Indonesia. Center for Economics and Development Studies (CEDS) Working Paper. Bandung: Padjadjaran University, Indonesia.

Suriyawan, J. (2001). Attitude of Second Lower Secondary School Students in Dramatic Arts College Toward Music Theory Course. Mahidol University.

Taylor, C. (1994). Multiculturalism: Examining the politics of recognition. Princeton University Press, 41 William St., Princeton, NJ 08540.

Suara, I. D. M., Gelgel, I. P., \& Yasa, I. W. S. (2018). Pitra yadnya implementation for Hindu heroes. International Journal of Social Sciences and Humanities, 2(3), 136-148. https://doi.org/10.29332/ijssh.v2n3.223 


\section{Biography of Authors}

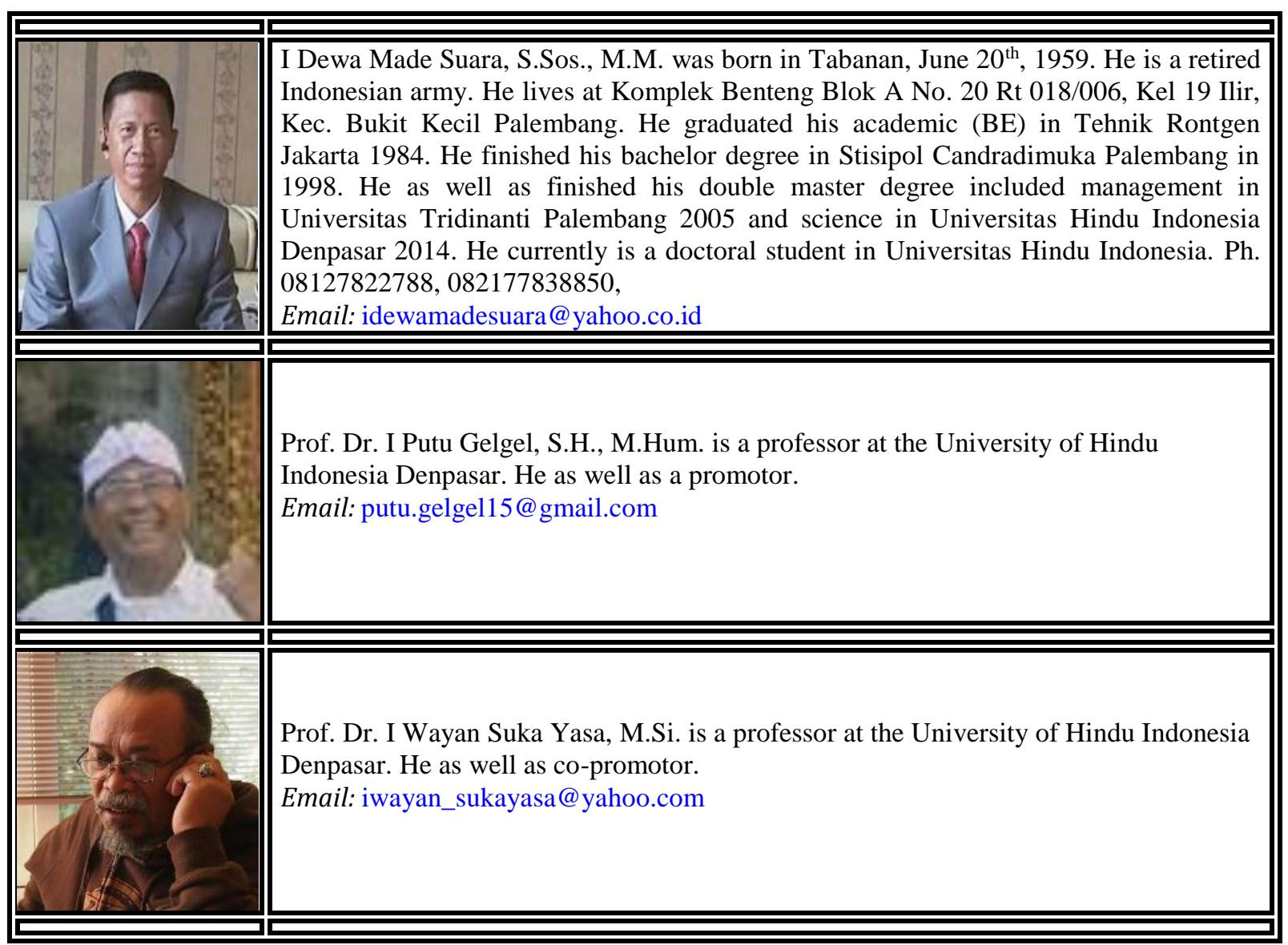

